\title{
Information services using problem-based learning (PBL) methods to increase the emotional quotient (EQ) of students
}

\author{
Neci Yalisma', Neviyarni ${ }^{2}$, Marjohan $^{3}$ \\ 1,2,3 Universitas Negeri Padang \\ *Corresponding author, e-mail: n3c1.y411sm4@gmail.com
}

\begin{abstract}
Emotion is a feeling that arises in students, both positive and negative, a phenomenon that often occurs in schools that there are still students who have negative emotions, such as being angry with friends in class, in this study students should be able to regulate emotions so as not to have a negative impact on themselves nor other people. This study aims to increase the emotional quotient of class $\mathrm{X}$ and XI students. This research is experimental research, the type of research used is a quasi-experimental design with a nonequivalent control group design. The sampling technique used was purposive sampling. The number of samples of 60 people who are categorized as low on the student's emotional quotient, the class sample is divided into two groups: 1) the experimental group of 30 people and 2) the control group of 30 people. The instrument used was a an emotional quotient questionnaire. The results of the emotional quotient show that there is an increase in the emotional quotient of students between the experimental group before and after the treatment of information services using the problem-based learning method is carried out, there is an increase in the emotional quotient of the control group students before and after being provided with information services without the problem-based learning method, there is a significant difference in the level students' emotional quotient between the experimental group that was provided with information services using the problem-based learning method and the control group that was provided with information services. Thus, information services using problem-based learning methods are effective in increasing students' emotional quotient.
\end{abstract}

Keywords: Information Services, Problem Based Learning, Emotional Quotient.

How to Cite: Yalisma, N., Neviyarni, N., Marjohan, M. (2021). Information services using problem-based learning (PBL) methods to increase the emotional quotient (EQ) of students. International Journal of Applied Counseling and Social Sciences. 2 (2): pp. 117-125, DOI: http://doi.org/10.24036/005414ijaccs

This is an open access article distributed under the Creative Commons 4.0 Attribution License, which permits unrestricted use, distribution, and reproduction in any medium, provided the original work is properly cited. @2021 by Author

\section{Introduction}

Education is a process of human interaction between educators and students to achieve educational goals. The process takes place in a certain environment using a variety of measures in accordance with Article 1 paragraph 1 of Law No. 20 of 2003 concerning the national education system explains that education is a conscious and planned effort to create an 
atmosphere of learning and the learning process so that students are actively able to develop their potential to have spiritual strength, religion, self-control, personality, intelligence, and noble character, and skills. which is needed by himself, society, nation and state (Syafril, 2012) But in reality, there are many various irregularities occurring in the school environment. One of the social problems facing Indonesia today is the prevalence of youth violence such as fights between students, extortion and other violence that often occurs in everyday life.

Based on data obtained from the KPAI, cases of violence and violence in the field of education have increased every year. The number of students as perpetrators of violence in schools has increased by 67 cases and students as perpetrators of brawl has increased by 46 cases in 2014. Furthermore, in 2015 the number of students as perpetrators of violence was 79 cases and students as perpetrators of violence had increased by 103 cases. This happens because there are students who are less able to control their own emotions (Hazliansyah, 2015).

In 2016 as much as 12.9\%, in 2017 it reached 14\% (Yusuf, 2018). Furthermore, the 2018 KPAI data explained that $40 \%$ of students reported experiencing physical violence by peers, $75 \%$ of students admitted to having committed violence at school, KPAI also noted that in the first 3 semesters in 2018, complaints in KPAI were dominated by physical violence, namely $72 \%$, while $9 \%$ of students complained about psychological violence, $4 \%$ for bullying, and $2 \%$ for sexual violence (Hilmi, 2017). Furthermore, the 2019 KPAI data recorded that there were 161 cases of violence in the world of education. There were 23 cases, $14.3 \%$ of children were victims of brawls, 31 cases of $19.3 \%$ of children who were perpetrators of brawls (Adriel \& Indrawati, 2019). Judging from its various types, students aged 13-17 in Indonesia tend to experience emotional violence compared to physical violence. A total of $70.98 \%$ boys and $88.24 \%$ girls have experienced physical violence. For the category of emotional violence, $86.65 \%$ boys and 96.22\% girls stated that they had experienced it (Gerintya, 2017).

The results of surveys in the 1970s and 1980s in America of parents and teachers revealed that adolescents experience emotional problems such as depression, irritability, difficulty in managing, are more nervous, and tend to be anxious, impulsive, and aggressive (Ginanjar, 2007). Emotional problems like this also occur in Indonesia, adolescents who like to think emotionally tend to get angry quickly, cannot solve the problems they face, and cause disputes in the social environment. Based on the results of Yuliani (2013) 's research on the negative emotions of class XI students of SMAN 1 Sungai Limau that the negative emotions of students that are very prominent are shown, namely angry emotions with a percentage of $43.8 \%$ because students are often humiliated, humiliated, cornered in front of other peers. This form of student emotion can trigger fights, berate with other verbal expressions. The results of Tumon's research (2014) explain that specific forms of adolescent behavior that are often done are satire at $36.2 \%$ and bully at $35.6 \%$. Meanwhile, what often happened and experienced by victims of violence was being insinuated by $36.2 \%$ and being bullied by $28.7 \%$. The causes of these problems occur due to family and peer factors. From the results of these studies, it is concluded that students today are difficult to control and regulate the emotions that happen to them, both those that occur to the perpetrators and victims of violence.

Triantoro \& Nofrans (2012) states that problems that can cause conflict are emotional in nature, which are related to feelings such as anger, ridicule, rejection, and feelings of fear. Individuals who have high emotional intelligence are certainly able to control their emotions properly and effectively. The results of Melianasari's (2016) study suggest that high emotions 
are shown by being disappointed, angry, and hateful, if left unchecked it can affect their survival. As studentss are less able to manage their emotional intelligence.

The results of Illahi \& Neviyarni's (2018) research on the relationship between emotional intelligence and adolescent aggressive behavior and its implications in guidance and counseling suggest that there is a significant negative relationship between emotional intelligence and students' aggressive behavior. This means that the higher the students 'emotional intelligence, the lower the level of students' aggressive behavior. This happens because emotional intelligence is one of the factors that can influence students 'aggressive behavior, but it is not the only factor that can influence students' aggressive behavior. So the efforts of the school counselor/counselor to prevent this aggressive behavior by controlling students' emotions well, the implications for guidance and counseling are providing information services with various materials, namely how to control emotions and understand the causes of emotions in adolescents.

Furthermore, Sahputra (2016) suggests that emotionally intelligent individuals find it easier to relate to other people because they are able to recognize other people's emotions, are calm, stable, and easy to make friends. Daud (2012) suggests that emotional intelligence is the ability to feel, understand, and effectively apply emotional sensitivity as a human source of energy, information, connections, and influences. Goleman (2019) states that intellectual intelligence (IQ) contributes $20 \%$ to success, while $80 \%$ is the contribution of other strengths, including the emotional intelligence factor. Efforts that researchers have made to improve students' emotional intelligence, in this case, use one of the guidance and counseling services, namely information services. The reason the researchers used this service was that it was found that the implementation of information services in schools has not been implemented optimally by the counselor, even though each service has been programmed in guidance and counseling services in schools. The Ministry of Education and Culture (2016) states that the implementation of each service both classically and the BK Teacher/Counselor group can collaborate with various methods containing strategies for guidance and counseling service activities to be carried out. Based on the problems that have been described, that researchers conducted research on "The Effectiveness of Information Services with Problem Based Learning Methods to Increase Emotional Quotient (EQ) Students of SMAN 1 JunjungSirih".

\section{Method}

The research method used by researchers is the experimental research method. This method is used through experiments between certain variables to see how far the treatment effect is between the experimental group and the control group. This type of experimental research used by researchers is quasi-experimental (quasi-experimental). According to Arifin (2014), quasi-experimental is a quasi-experimental that aims to predict the conditions that can be achieved through actual experiments, but there is no control and manipulation of all relevant variables. The quasi-experimental design used by researchers was the nonequivalent control group design.

Based on the description above, it can be concluded that this study seeks to determine how far the difference between the experimental group and the control group is in increasing students' emotional quotient. The population in this study were 527 people. While the sampling used in this study is a non probability sampling technique with purposive sampling. 
Sugiyono (2013) states that purposive sampling is a sampling technique with a variety of specific or purposeful considerations. The sample, which was categorized as having a low level of emotional quotient, was used by the researchers as a sample in the study. The sample consisted of two groups, the experimental group as many as 30 people and the control group as many as 30 people. The data collection technique used in this study was an instrument, the research instrument was a questionnaire.

Arikunto (2019) questionnaires are many written questions that are used to obtain information from respondents in the sense of reports about their personalities or things they know. The questionnaire that is distributed is designed according to the needs and distributed to the respondents. So a questionnaire is a set of questions that must be answered by the respondent in writing which is used to obtain various information directly provided by the respondent. The type of questionnaire used by researchers is a Likert scale questionnaire which has five alternative answers where a questionnaire provides a choice of statements in the form of a checklist on one of the answers. Iskandar (2009) states that the questions or statements to be answered by respondents are in the form of a Likert scale which has a gradient from very positive to very negative which is expressed in the following words.

Table 1. Scoring Guidelines

\begin{tabular}{llcc}
\hline No & Alternative Answers & $\begin{array}{r}\text { Positive Statement } \\
\text { Score }\end{array}$ & $\begin{array}{c}\text { Negative Statement } \\
\text { Score }\end{array}$ \\
\hline 1 & Perfectly fit & 5 & 1 \\
2 & Corresponding & 4 & 2 \\
3 & Sufficiently Appropriate & 3 & 3 \\
4 & Incorrect & 2 & 4 \\
5 & Very Incorrect & 1 & 5 \\
\hline
\end{tabular}

Data processing to determine the level of student's emotional quotient using SPPS version 22.

\section{Results and Discussion}

Information services provided using the problem-based learning method to increase students' emotional quotient are thought to be more effective than information services without using the problem-based learning method. The results of the hypothesis analysis are detailed as follows.

Based on table 2 above, the Asymp value is obtained. Sig. (2-tailed) for the two-sided test, a significant value of 0.000 means that it is smaller than the significance value of $0.05(0.000$ $<0.05)$.then $\mathrm{H} 0$ is rejected and $\mathrm{H} 1$ is accepted, meaning that there is a significant difference in the level of students' emotional quotient between the experimental group that was given information service treatment using the problem-based learning method and the control group who was provided with information services without the problem-based learning method. 
Table 2. Result Analysis of Kolmogorov Smirnov 2 Test Independent Sampels on Posttest Emotional Quotient Students Experiment Group with Control Group

\begin{tabular}{llr}
\hline & & VAR00001 \\
\hline Most Extreme & Absolute & .733 \\
Differences & Positive & .000 \\
& Negative & -.733 \\
Kolmogorov-Smirnov Z & & 2.840 \\
Asymp. Sig. (2-tailed) & & .000 \\
& & \\
\hline
\end{tabular}

It can be concluded that information services using problem-based learning methods are more effective in increasing students' emotional quotient than information services without problem-based learning methods. It can be seen that the graph of the change in students' emotional quotient score in the experimental group is as follows.

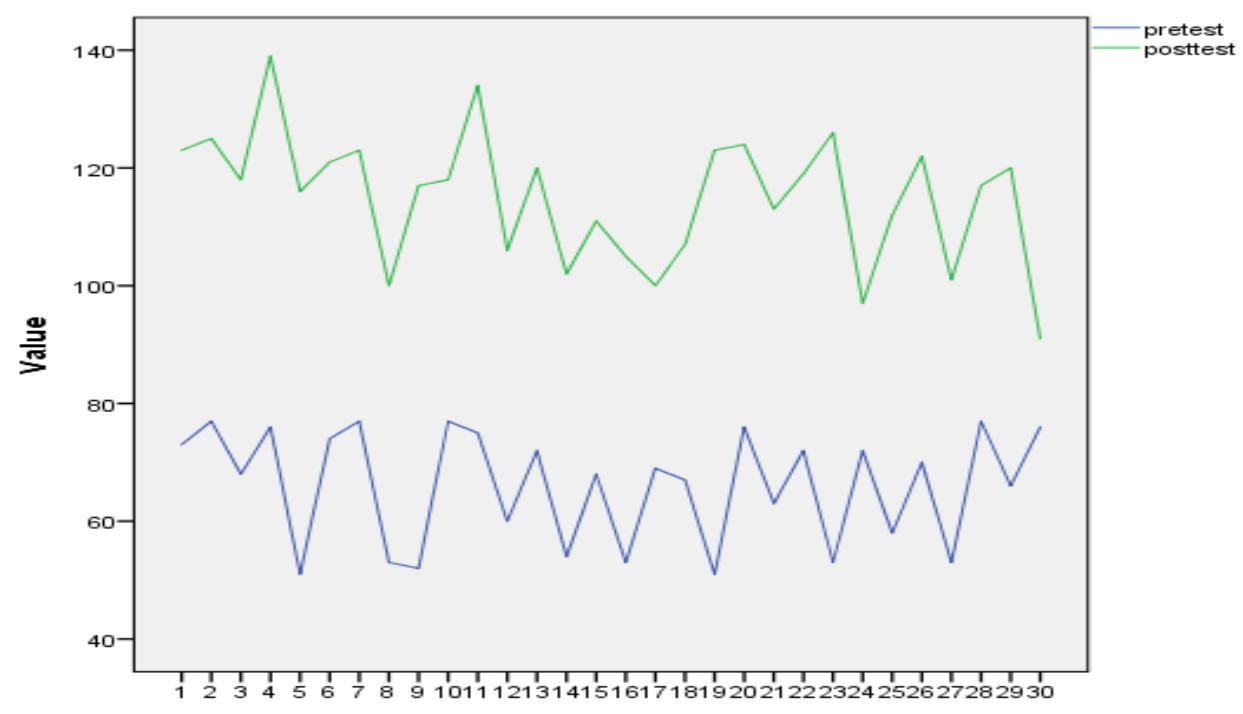

\section{Chart 1. The Difference in the Emotional Quotient Score of the Experiment Group Students Before and After being provided with Information Services using the Problem Based Learning Method}

Based on graph 1 above, it can be seen that there is an increase in the score of students' emotional quotient before and after being given information services using the problem based learning method. From the change score above, it shows that information services using the problem-based learning method can increase students' emotional quotient. This conclusion does not mean to conclude that the information services provided without using problembased learning methods cannot increase student emotional. Information services provided without using problem-based learning methods can also increase student emotionality, this is as illustrated in the graph below. 


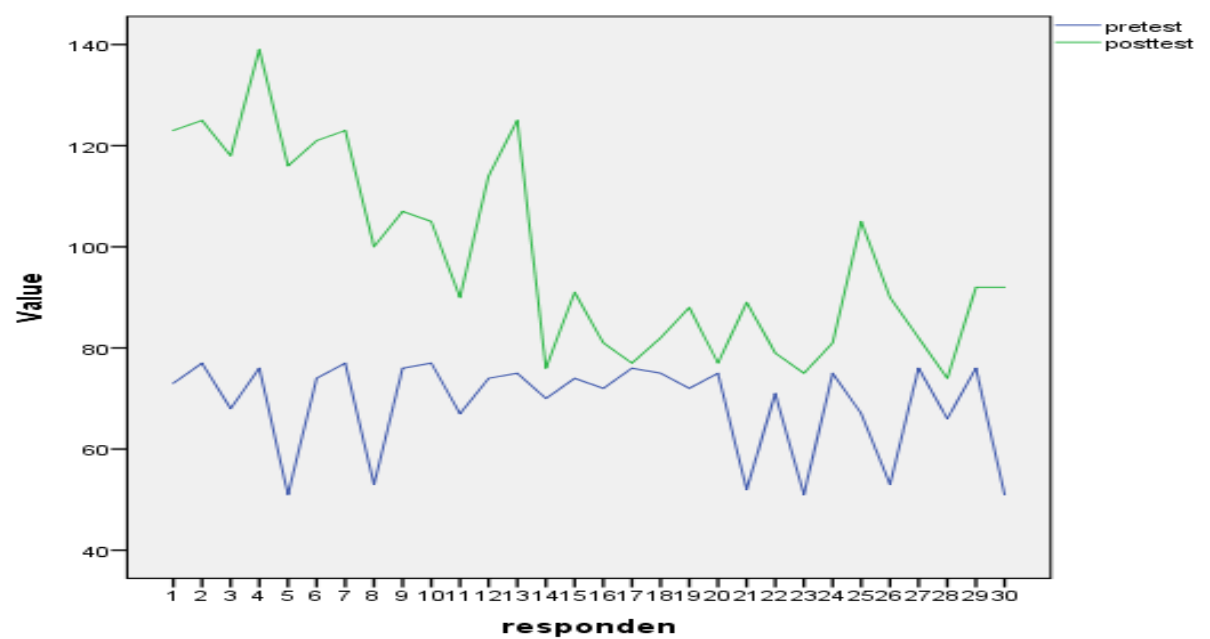

Chart 2. The Difference in the Emotional Quotient Score of the Control Group Students Before and After being provided with Information Services without using the Problem Based Learning Method

Based on the results of the graph above, there was an increase in students' emotional quotient scores before and after being provided with information services without using the problem-based learning method. This shows the conclusion that information services without using problem-based learning methods can increase students' emotional quotient. However, after testing the hypothesis between the experimental group and the control group it concluded that the information services provided by the problem-based learning method were more effective than information services without the problem-based learning method to increase students' emotional quotient.

The facts that the researchers found from the results of the hypothesis test above support the theory that the problem-based learning method is more effective in the teaching and learning process (Arends, 2015). There are several reasons that the information services provided using the problem-based learning method are proven to be more effective in increasing students' emotional quotient compared to information services without using the problem-based learning method. First, this problem-based learning method deals with the use of intelligence from within individuals who are in a group / environment to solve problems that are meaningful, relevant and contextual. The application of problem based learning also demands readiness from the teacher as a facilitator and is able to stimulate the thinking skills of students (Rusman, 2012).

Information services using the problem-based learning method in practice require students to understand problems deeply and repeatedly at each step, namely student orientation to a problem, organize students to learn, guide individual or group investigations, develop and present work, analyze and evaluate the solving process. problem. Each step taken can enrich students 'cognition about information service material, especially efforts to increase students' emotional quotient so that students are able to have a good attitude in managing and regulating their emotions well. Second, the problem-based learning method in practice is a student-centered learning method while the conventional method is an educator-centered learning method. The problem-based learning method requires students to be more active in learning than $\mathrm{BK} /$ counselors who only function as regulators in the information service 
process (Arends, 2015). Information services with the PBL method can also be used for other needs, such as increasing habitual learning (Nova, Firman, \& Sukmawati, 2016) and increasing critical thinking skills (Subekti, 2015). It could even be used to improve career planning (Rizka, 2017). These results are consistent with previous research, namely the PBL method to help students understand the information provided. In addition, PBL makes students more interested in participating in learning, developing independent learning skills, developing the scope of knowledge, and developing analytical skills (Huo, Yang, \& Gong, 2016; Imran et al., 2015; Pan, 2014).

Based on the results of this study, counseling teachers should use problem-based learning methods in providing information services to increase students' emotional quotient. Because this research is an experimental study tested in a limited group, this research cannot be generalized to a wider group of students. Therefore, it is recommended that other researchers be able to carry out further research so that it can be used with a wider group of students.

\section{Conclusions}

Based on the results of this study, it was concluded that information services using the problem-based learning method were effective in increasing students' emotional quotient. The results showed an increase in students' emotional quotient after being provided with information services using the problem-based learning method. This can occur because the problem-based learning method provides opportunities for students to explore a material that is studied at each step, namely student orientation to a problem, organizing students to learn, guiding individual and group investigations, developing and presenting work, analyze and evaluate the problem-solving process. This deeper process is also able to enrich students ' cognition about information service materials, especially efforts to increase students' emotional quotient so that students have the correct emotional attitude in everyday life. In addition, the problem-based learning method is a student-centered method that requires students to be more active in the learning process than the BK/counselor teacher who only functions as a facilitator.

\section{References}

Adriel, Y., \& Indrawati, E. S. (2019). Hubugan Antara Konformitas Teman Sebaya Dengan Perilaku Bullying Pada Siswa Kelas Xii Smk Teuku Umar Semarang. Empati, 8(1), 271276.

Arends, R. I. (2015). Learning to teach Tenth Edition. America: McGraw Hill Education

Arifin, Z. (2014). Penelitian pendidikan. Bandung: Remaja Rosdakarya.

Arikunto, S. (2019). Prosedur penelitian suatu pendekatan praktis. Jakarta: Rineka Cipta.

Daud, F. (2012). Pengaruh kecerdasan emosional (EQ) dan motivasi belajar terhadap hasil belajar Biologi siswa SMA 3 Negeri Kota Palopo. Jurnal Pendidikan dan Pembelajaran (JPP), 19(2), 243-255.

Faturochman. (2002). Keadilan perspektif psikologi. Yogyakarta: Unit Penerbit Fakultas Psikologi UGM.

Gerintya, Scholastica. (2017). 73,7 Persen anak indonesia mengalami kekerasan di rumahnya sendiri. Tirto.id Berita Online. Diakses dari https://tirto.id/737-persen-anak-indonesia- 
mengalami-kekerasan-di-rumahnya-sendiri-cAnG. Pada tanggal 28 Oktober 2019. Jam 19:33 WIB.

Ginanjar, A. (2008). Emotional spiritual quetiont. Jakarta: ARGA.

Goleman, D. (2019). Emotional intelligence: mengapa EI lebih penting daripada IQ. Alih Bahasa: T.Hermaya. Jakarta: Gramedia Pustaka Utama.

Hazliansyah. (2015). KPAI: Kasus bullying di sekolah meningkat selama 2015. Republika.co.id Berita Online. Diakses dari http://nasional.republika.co.id/berita/nasional/umum/15/12/30/o067zt280-kpai-kasusbullying-di-sekolah-meningkat-selama-2015. Pada tanggal 17 Oktober 2019. Jam 12:14 WIB.

Hilmi, Alfan. (2018). KPAI: 84 persen siswa alami kekerasan di sekolah. Tempo.coBerita Online. Diakses melalui https://gaya.tempo.co/read/1259058/demo-di-dpr-motif-pelajar lakukanunjuk-rasa-menurut-ketua-kpai. Pada tanggal 23 Agustus 2018. Jam 13.20 WIB.

Huo, Y., Yang, J., \& Gong, Z. (2016). Exploration and Practice of PBL in Pharmacology Experiment Teaching. The Journal of Medical Theory and Practice, 29(14).

Illahi, U., Neviyarni, N., Said, A., \& Ardi, Z. (2018). Hubungan antara kecerdasan emosi dengan perilaku agresif remaja dan implikasinya dalam bimbingan dan konseling. JRTI (Jurnal Riset Tindakan Indonesia), 3(2), 68-74.

Iskandar. (2009). Metodologi penelitian pendidikan dan sosial. Jakarta: Gaung Persada Press.

Kemendikbud. (2016). Panduan operasional penyelenggaraan bimbingan dan konseling sekolah menengah atas. Jakarta.

Melianasari, D. (2016). Penerapan layanan bimbingan kelompok melalui teknik permainan simulasi dan untuk meningkatkan kecerdasan emosi Siswa. PEDAGOGIA, 14(2).

Nova, L. M., Firman, F., \& Sukmawati, I. (2016). Efektifitas Layanan Informasi dengan Pendekatan Problem Based Learning Untuk Meningkatakan Kebiasaan Belajar Siswa. Jurnal Ilmiah Konseling.

Rusman. (2012). Model-model pembelajaran dalam mengembangkan profesionalisme guru. Jakarta: Rajawali Pers.

Rizka, Z. (2017). Effectiveness of Using Inforamation Servise with the Problem Based Learning Model in Improving Career Planning in Senior High Scholl Student. Universitas Negeri Padang.

Sahputra, D., Syahniar, S., \& Marjohan, M. (2016). Kontribusi kepercayaan diri dan kecerdasan emosi terhadap komunikasi interpersonal siswa serta implikasinya dalam pelayanan bimbingan dan konseling. Jurnal Konselor, 5( 3), 182-193.

Santrock, W. Jhon. (2003). Adolence (perkembangan remaja). Alih Bahasa Shinto B. Adelar. Jakarta: Erlangga.

Subekti, L. (2015). Model Problem Based Learning dalam Layanan BK untuk Meningkatkan Keterampilan Berpikir Kritis. Jurnal Penelitian Tindakan Kelas, 16(3), 60-67.

Sugiyono. (2013). Metode Penelitian Pendidikan: Pendekatan kuantitatif, kualitatif, dan $R \mathcal{E} D$. 
Bandung: Alfabeta.

Syafril. (2012). Pengantar Pendidikan. Padang: Sukabina Press.

Triantoro \& Nofrans. (2012). Manajemen Emosi. Jakarta: Bumi Aksara.

Tumon, M. B. A. (2014). Studi deskriptif perilaku bullying pada remaja. CALYPTRA. Jurnal Ilmiah Mahasiswa. 3(1), 1-17.

Yuliani, R. (2013). Emosi negatif siswa kelas XI SMAN 1 Sungai Limau. Jurnal Ilmiah Konseling, 2(1), 151-155.

Yusuf, Yan. (2018). Sepanjang 2018 delapan pelajar di jakarta tewas akibat tawuran. Sindonews.com Berita online. Diakses melalui https://metro.sindonews.com/read/1363298/170/sepanjang-2018-delapan-pelajar-dijakarta-tewas-akibat-tawuran-1544965546. 